\section{Ks. Grzegorz Rafiński}

Gdańskie Seminarium Duchowne, Gdańsk g.rafi@wp.pl

DOI: http://dx.doi.org/10.12775/BPTh.2016.004

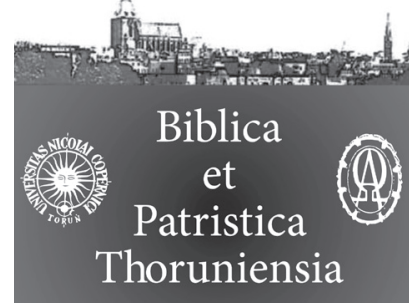

9 (2016) 1: 83-95

ISSN (print) 1689-5150

ISSN (online) 2450-7059

\title{
Ideał tolerancji w świetle przesłanek zawartych w Listach św. Pawła (część pierwsza: zagadnienia wstępne)
}

\author{
The idea of tolerance in light \\ of the premises contained in the Letters of St. Paul \\ (Part One: preliminary study)
}

Streszczenie. Ideał tolerancji, który odgrywa ważną rolę w dzisiejszym świecie, powinien być poddany refleksji w świetle Słowa Bożego. Św. Paweł nie używa słowa tolerancja, ale w kilku tekstach pisze o fenomenie, który opisuje to słowo, a mianowicie w 1 Kor 8-10, a także w 1 Kor 5,1-13; 6,1-11; Rz 14 (gdzie używa czasownika „sądzić” -

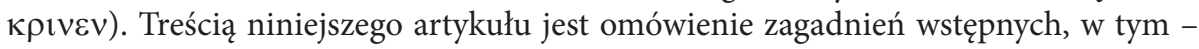
analiza 1 Kor 8-10. Chrześcijanie muszą dawać świadectwo tolerancji Jezusa (por. Mk 9,40: „Kto bowiem nie jest przeciwko nam, ten jest $\mathrm{z}$ nami”). Tolerancja oznacza znoszenie drugiego w jego inności. Rozumienie orędzia Jezusa dokonuje się w dialogu $\mathrm{z}$ inaczej myślącymi i z niechrześcijanami. Św. Paweł w swych listach koryguje błędne rozumienie tolerancji przez adresatów listów. W 1 Kor 8-10 niewłaściwą postawę tych, którzy posiadali „wiedzę" płynącą z Ewangelii, św. Paweł opisuje zdaniem: „«wiedza» wbija w pychę" (1 Kor 8,1). Korektę ich postawy zawiera w zdaniu: „Miłość buduje” (1 Kor 8,1). Miłość jest w tym zdaniu równoważnikiem zalecanej przez św. Pawła postawy tolerancji wobec tych, którzy nie przyjęli w pełni ewangelicznej „wiedzy”. Wynika $\mathrm{z}$ tego, że tolerancja nie jest wartością autonomiczną, absolutną, ale jest podporządkowana miłości. Zasadę tę należy traktować jako naczelną tezę, której podlega wszystko, co św. Paweł pisał na temat tolerancji (i nietolerancji) w innych tekstach, które będą analizowane w kolejnym naszym artykule na łamach „Biblica et Patristica Thoruniensia".

Summary. The idea of tolerance, which plays an important role in today's world, should be reflected on in light of the Word of God. St. Paul never uses the word tolerance, however, in some texts he writes about the phenomenon which describes this word, namely in 1 Cor 8-10 and in 1 Cor 5:1-13; 6:1-11; Rom 14 (where he uses the verb "to

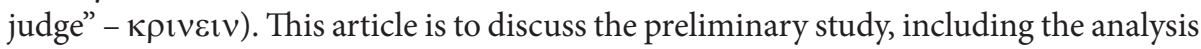
of 1 Cor 8-10. Christians must follow Jesus and be tolerant (cf. Mk 9:40: "Whoever is 
not against us is for us ${ }^{1}$ "). Tolerance means to accept somebody's individuality. Understanding the message of Jesus is achieved only through dialogue with those who have different views and beliefs, and non-Christians. In his letters, St. Paul corrects the way of understanding of tolerance by the addressees of the letters. In 1 Cor 8-10, St. Paul describes the inappropriate attitude of those who had "knowledge", saying that "knowledge puffs a person up with pride" (1 Cor 8:1). He corrects their attitudes by saying: "Love builds up" (1 Cor 8:1). In this sentence, love is the equivalent of tolerance toward those who have not acquired the complete Gospel "knowledge" recommended by St. Paul. Thus, tolerance is not any autonomous or absolute value, but it is subordinate to love. This principle should be regarded as the fundamental thesis, which governs everything St. Paul ever wrote on tolerance (and intolerance) in other texts that will be analyzed in our next article published in "Biblica et Patristica Thoruniensia".

Słowa kluczowe: tolerancja; nietolerancja; sądzić.

Keywords: tolerance; intolerance; to judge.

Przygarniajcie siebie nawzajem” - tak napisał św. Paweł do chrześcijan
w Rzymie (Rz 15,7) - wiedząc, że byli wśród nich „mocni [w wierze]” i „słabi” (Rz 15,1), a do chrześcijan z Filippi skierował apel: „Niech będzie znana wszystkim ludziom wasza wyrozumiała łagodność” (Flp 4,5). Tylko, jak rozumieć te wezwania w praktyce? Świadczą one o tym, że św. Paweł zakładał, iż Kościół nie jest i nie będzie nigdy gronem ludzi bez skazy i jest w nim miejsce dla „słabych”, ale czy z tego wynika, że dozwolone jest podejmowanie przez chrześcijan indywidualnych decyzji o zawieszaniu egzekwowania wymogów Ewangelii? Gdzie jest, w takim przypadku, granica między „przygarnianiem słabych”, „wyrozumiałą łagodnością” a zdradą Ewangelii? Dochodzi do tego pytanie o stosunek chrześcijan do tych, którzy nie należą do Kościoła. Z pytaniami tymi łączy się pojęcie tolerancji, które weszło przebojem do współczesnego słownika, zajmując w nim poczesne miejsce. Moda na to słowo jest swoistym „znakiem czasu”, który muszą odczytać dzisiejsi chrześcijanie.

Św. Paweł nie używa słowa „tolerancja” (i „nietolerancja”), ale pisze w swoich listach o tym fenomenie, gdy używa czasownika kpıvıv („sądzić”). Szczególne natężenie tej terminologii występuje w 1 Kor 5,1-13, w 1 Kor 6,1-11, w Rz 14, a także w 1 Kor 8-10². Teksty te mają charakter okazjonalny, są reakcją

1 All citations from: Good News New Testament. Today's English Version.

2 Czasownik кpıveıv występuje w: 1 Kor 5,3.12.12.13; 6,1.2.2.3.6; 10,15.29 (oprócz tego: w 1 Kor 2,2; 4,5; 7,37; 11,13,31,32), w Rz 14,3.4.5.5.10.13.13.22 (oprócz tego: w Rz 2,1.1.1.3.12.16.27; 3,4.6.7). Poza 1 Kor i Rz termin אpıveıv występuje sporadycznie w: 2 Kor (dwa razy), Kol, 2 Tes, 2 Tm, Tt (po jednym razie). 
na szczegółowe kwestie, które nurtowały adresatów listów św. Pawła, ale można na ich podstawie uzyskać spójny obraz poglądów św. Pawła na tolerancję (i nietolerancję).

Treścią niniejszego artykułu jest omówienie zagadnień wstępnych, w tym analiza 1 Kor 8-10. Analizę 1 Kor 5,1-13; 6,1-11; Rz 14 przeprowadzimy w drugiej części artykułu, która zostanie opublikowana w kolejnym numerze BPTh. $\mathrm{W}$ analizowanych perykopach znajdziemy odpowiedzi na frapujące pytania: Czy właściwe jest współistnienie tolerancji i nietolerancji w różnych decyzjach chrześcijanina? Jeśli tak, to w stosunku do kogo? W jakich okolicznościach? Dlaczego?

Analizę każdego tekstu źródłowego rozpoczniemy od postawienia tezy wynikającej z danego tekstu. Następnie opiszemy niewłaściwe rozumienie tolerancji przez chrześcijan, do których tekst jest adresowany, powstałe w okresie między przyjęciem przez nich Ewangelii a powstaniem tekstu. W kolejnym punkcie analizy tekstu skupimy się na ukazaniu reakcji św. Pawła na błędne rozumienie Ewangelii (etap redakcji listów), kończąc uwagami na temat aktualności orędzia św. Pawła na temat tolerancji³

Nauka św. Pawła stanowi odpowiedź na pytania, które może zadawać sobie dzisiejszy czytelnik Starego Testamentu, który natrafia w Księdze Jozuego na wiersze traktujące o tzw. prawie „cheremu” (Joz 11,14-15; por. Pwt 7,1-2). Choć św. Paweł nie nawiązuje bezpośrednio do tego prawa, to jednak jego nauka stanowi rekapitulację refleksji na temat tolerancji obejmującą zarówno Stary, jak i Nowy Testament, czemu damy wyraz w drugiej części artykułu.

\section{Tolerancja - pojęcie „podejrzane” w słowniku chrześcijan? Niekoniecznie!}

Pojęcie tolerancji stało się „podejrzane” w niektórych kręgach chrześcijan ze względu na to, że należy do słownika ideologii dystansujących się od chrześcijaństwa ${ }^{4}$. Nie brakuje jednak w środowisku chrześcijańskim zwolenników poglądu, iż tolerancja jest wartością pozytywną, nieodzowną w życiu chrześcijan, dlatego pojęcia tolerancji nie należy wykluczać ze słownika chrześcijan i należy

3 Aktualizacja tekstu nie jest „pobożnościowym dodatkiem” do egzegezy, ale jest integralną częścią analizy tekstów biblijnych, na co zwraca uwagę: W. Egger, Metodologia del Nuovo Testamento. Introduzione allo studio scientifico del Nuovo Testamento, Bologna 1989, s. $225-240$.

4 Tolerancja jest kategorią etyczną promową przez ideologię socliberalną i stanowi również integralną część tzw. politycznej poprawności. 
poddać je pogłębionej refleksji w świetle Ewangelii. Zwolennikiem takiego myślenia jest Anton Grabner-Haider, według którego „tolerancja oznacza uznanie każdego człowieka za możliwego partnera dialogu i za ty chciane przez Boga" ${ }^{\text {. }}$. Autor ten zauważa, że „rozumienie orędzia Jezusa dokonuje się w dialogu [...]. Podobnie jak wszelka prawda, tak i prawda Ewangelii jest prawdą o charakterze dialogowym. Właśnie $\mathrm{w}$ dialogu, rozmowie z inaczej myślącymi i z niechrześcijanami ukazuje się prawda Jezusa. Świadomość tego domaga się od chrześcijan zdecydowanej tolerancji. [...] Chrześcijanie muszą dawać świadectwo tolerancji Jezusa: «Kto bowiem nie jest przeciwko nam, ten jest $\mathrm{z}$ nami» (Mk $9,40)$ - mówił swoim uczniom. Jezus żył dla wszystkich i grzechy wszystkich zaniósł na krzyż. Tolerancja oznacza właściwie znoszenie drugiego w jego inności. Noszenie brzemienia drugiego, albo przyjęcie brata jako zbawczy krzyż jest jednym z podstawowych wymogów Ewangelii (Ga 6,2). Tam, gdzie między chrześcijanami nie ma tolerancji, niewłaściwie jest rozumiane prawo Chrystusa. Uderzająca jest tolerancja Pawła Apostoła wobec jego wrogów: «a jeśli odczuwacie coś inaczej, i to Bóg objawi» (Flp 3,15). [...] Tolerancja nie oznacza całkowitego czy nawet częściowego wyrzeczenia się własnych przekonań. Tolerancja nie wymaga pomniejszania czy uszczuplenia w czymkolwiek orędzia Ewangelii, wzywa jedynie do dialogu"6.

Podzielamy pogląd A. Grabner-Haidera, że tolerancja jest wartością pozytywną i konieczną w życiu chrześcijan żyjących w wielokulturowym świecie i że należy uznać każdego człowieka za możliwego partnera dialogu. Wniosek taki wypływa z tekstów zawartych w listach św. Pawła, które przeanalizujemy w niniejszym artykule. Można znaleźć analogie pomiędzy realiami życia Kościoła czasów św. Pawła i realiami, w których żyje dziś Kościół, które sprawiają, że wskazówki św. Pawła w tym zakresie nabierają charakteru ponadczasowego ${ }^{7}$.

Słowo tolerancja wywodzi się z języka łacińskiego (łac. tolerantia), w którym oznacza „znoszenie, wytrwałość, cierpliwość, zrzeczenie się czegoś”. W niniejszym artykule pragniemy spojrzeć na fenomen tolerancji niejako oczyma św. Pawła, a jego punkt widzenia traktować jako wzorcowy dla nas. Apostoł zwraca się z pouczeniami do tych, którzy, jak on, przyjmują istnienie

5 Zob. A. Grabner-Haider, Tolerancja, w: Praktyczny Słownik Biblijny, Opracowanie zbiorowe katolickich i protestanckich teologów, A. Grabner-Haider (red.), T. Mieszkowski, P. Pachciarek (przekład i opracowanie), Warszawa 1995 (oryginał: Freiburg im Breisgau 1969), s. 1320-1321.

6 Ibidem, s. 1320-1321.

7 Tolerancja jest problemem dyskutowanym od wieków przez filozofów, historyków i teologów. Zob. www.ptta.pl/pef/pdf/t/tolerancja.pdf.

8 Ksiądz Alojzy Jougan, Słownik kościelny łacińsko-polski, Warszawa 1992, s. 688. 
obiektywnej prawdy, która zawarta jest w Ewangelii ${ }^{9}$. Przy tym założeniu tolerancja oznacza, zgodnie ze źródłosłowem łacińskim, „zrzeczenie się” egzekwowania prawdy od tych, którzy nie stoją na gruncie Ewangelii ${ }^{10}$. Jest, jak zauważa cytowany przez nas A. Grabner-Heider, „znoszeniem drugiego w jego inności” (w języku potocznym mówimy o „przymykaniu oczu” na słabości innych, co dobrze oddaje treść powyższej definicji). Równocześnie, tolerancja „nie oznacza całkowitego czy nawet częściowego wyrzeczenia się własnych przekonań i nie wymaga pomniejszania czy uszczuplenia w czymkolwiek orędzia Ewangelii”, a jedynie „oznacza uznania każdego człowieka za możliwego partnera dialogu i za ty chciane przez Boga”. Przeciwnie, nietolerancja wobec tych, którzy nie stoją na gruncie obiektywnej prawdy, oznacza domaganie się bezwarunkowego egzekwowania prawdy $z$ ich strony.

\section{Okoliczności powstania tekstów źródłowych na temat tolerancji w Listach św. Pawła}

Wskazane na wstępie teksty źródłowe odnoszą się do tolerancji (i nietolerancji) w rozumieniu podanym wyżej. Zawarte są one w Listach św. Pawła, które są medium dialogu między Apostołem i adresatami, w tym - z nami, dlatego należy je postrzegać w szerszym kontekście rozwojowym:

a) Etap pierwszy: ustne głoszenie Ewangelii przez św. Pawła w zakładanych przez niego Kościołach. W skład kerygmy wchodziło nauczanie łączące się z problematyką tolerancji. Św. Paweł nauczał o wolności chrześcijańskiej. Z tego etapu pochodzi zdanie zapisane w 1 Kor 6,12; 10,23: „Wszystko mi wolno”, będące elementem nauczania św. Pawła (lub już zdeformowaną przez Koryntian jego postacią). Pierwszy kerygmat Paw-

9 W publikacjach na temat tolerancji rozróżnia się tzw. tolerancję negatywną, w której nie neguje się istnienia i możliwości dojścia do obiektywnej prawdy, a także tzw. tolerancję pozytywną, w której nie uznaje się istnienia prawdy obiektywnej i dopuszcza wszelkie postawy, działania i poglądy, jako równouprawnione (zob. www.stacja7.pl). Tolerancja pozytywna jest spuścizną postmodernizmu i jest nie do pogodzenia z Biblią. Dla chrześcijan obiektywna prawda, będąca fundamentem ich życia, jest zawarta w Piśmie świętym (interpretowanym w Kościele).

10 Tolerancja oznacza, według innej definicji, „świadomą zgodę na wyznawanie i głoszenie przez innych ludzi poglądów, z którymi się nie zgadzamy, oraz na wybór sposobu życia uważanego przez nich za właściwy, chociaż go nie aprobujemy” (zob. www.stacja7.pl). Pojęcie zgody można zastąpić słowem „poszanowanie” („poszanowanie czyichś poglądów, wierzeń, upodobań, różniących się od własnych”; Słownik PWN: zob. sjp.pwn.pl/slowniki/ tolerancja.htm). 
ła zawierał też głoszenie wiary w jednego Boga połączone $\mathrm{z}$ krytyką idolatrii, czego ślad znajdujemy w 1 Tes 1,9-10 (zob. aluzję do pierwszej wizyty Pawła w Tesalonice). Śladem tego etapu nauczania jest też 1 Kor 8,1.4-6 (treść nauczania św. Pawła wprowadzają zwroty: „posiadamy wiedzę”, „wiemy dobrze”). Aspekt eschatologiczny nauczania Pawła na tym etapie jest utrwalony w słowach zapisanych w 1 Kor 6,2-3: „Czy nie wiecie, że święci będą sędziami tego świata? [...] Czyż nie wiecie, że będziemy sądzili także aniołów?” oraz w 1 Kor 6,9: „Czyż nie wiecie, że niesprawiedliwi nie posiądą królestwa Bożego?” Z tego etapu pochodzi też nauczanie o tym, że chrześcijanie są członkami ciała Chrystusa (1 Kor 6,15: „Czy nie wiecie, że ciała wasze są członkami Chrystusa?”) i o ciele jako świątyni Bożej lub świątyni Ducha Świętego (1 Kor 6,19: „Czyż nie wiecie, że ciało wasze jest świątynią Ducha Świętego?”), a także zdanie zapisane w 1 Kor 6,19: „Za [wielką] bowiem cenę zostaliście nabyci”"11.

b) Etap drugi, w którym ci, którzy przyjęli Ewangelię, po pożegnaniu św. Pawła starali się wcielać w życie jego nauczanie. Na tym etapie nie brakowało nieporozumień. Nauczanie św. Pawła bywało źle rozumia$\mathrm{ne}^{12}$. Dowodem na to jest korekta, którą Apostoł był zmuszony wprowadzić do reguły: „Wszystko mi wolno”, zapisana w 1 Kor 6,12; 10,23 („ale nie wszystko przynosi korzyść..., ale ja niczemu nie oddam się w niewolę..., ale nie wszystko buduje”). „Wiedza” (zob. 1 Kor 8,1.4-6) uzyskana od św. Pawła prowadziła do błędnych wniosków, co było powodem interwencji Apostoła zapisanej w 1 Kor 8-10. Powodem błędnej recepcji nauczania św. Pawła bywało uleganie nawróconych na chrześcijaństwo wpływom „tego świata” (por. 1 Kor 5,6-11, gdzie św. Paweł piętnuje niemoralność Koryntian trwającą mimo skierowania do nich wcześniejszego listu, w którym Apostoł nakazywał im, aby nie obcowali $\mathrm{z}$ rozpustnikami). Św. Paweł posiadał wiedzę o wielu różnych nieporozumieniach dzięki kolejnym wizytom w młodych Kościołach, otrzymywanym listom i przyjmowanym wysłannikom. Z listów św. Pawła możemy wywnioskować, jakie były błędne „schematy” postępowania adresatów listów związane z problemem tolerancji (wcale nieodległe od nieporozumień istniejących dzisiaj). W różnych częściach Kościoła w Koryncie ${ }^{13}$

11 Zob. M. Pesce, Le due fasi della predicazione di Paolo. Dall'evangelizzazione alla guida della comunità, Bologna 1994, s. 19-34.

12 Por. 2 P 3,15-16.

13 Św. Paweł ewangelizował w domostwach, które stawały się bazami jego działalności. Każde domostwo mogło być zamieszkałe nawet przez 50 osób. Taka struktura Kościoła, a także przywiązanie Koryntian do ewangelizatorów, od których otrzymywali chrzest 
dominowały przeciwstawne opcje: $\mathrm{w}$ niektórych panował przesadny rygoryzm sprzyjający nietolerancji wobec „słabych” w wierze, a w innych laksyzm owocujący zbytnią tolerancją wobec zła popełnianego przez współwyznawców. Niezrozumienie Ewangelii przez tych, którzy przyjęli Ewangelię, cechowało członków Kościołów założonych przez św. Pawła, ale także chrześcijan z Kościoła w Rzymie założonego przez innych ewangelizatorów (zob. Rz 14,1, gdzie św. Paweł wytyka chrześcijanom z Rzymu „spieranie się o poglądy” dotyczące pokarmów i dni świętych).

c) Etap trzeci, w którym św. Paweł śle listy z wyjaśnieniami doktrynalnymi i korektami błędnego rozumienia swego nauczania, w tym z korektami błędnych postaw związanych z fenomenem tolerancji. Celem św. Pawła jest prowadzenie poprzez listy wspólnot już istniejących ku dalszemu ich rozwojowi w wierze.

d) Etap czwarty: aktualizacja tekstów źródłowych. Podkreślić należy, że teksty źródłowe, które będziemy poniżej omawiali, dotyczą nieporozumień zaistniałych wśród chrześcijan z Koryntu i z Rzymu, czyli w środowiskach wielkomiejskich, w których wyzwaniem dla chrześcijan była wielokulturowość (List do Rzymian został napisany z Koryntu, co stanowi dodatkowy łącznik Listów do Koryntian i Listu do Rzymu w świadomości św. Pawła). Sugestie św. Pawła są niezwykle aktualne dziś, gdy Kościół musi odnajdywać swoje miejsce w wielokulturowym świecie.

\section{Zasada naczelna: tolerancja nie jest wartością absolutną, ale jest funkcją miłości (1 Kor 8-10)}

Założenie, że tolerancja jest niezbędna $\mathrm{w}$ relacjach międzyludzkich, może prowadzić do jej absolutyzowania (trzeba być tolerancyjnym „zawsze i wszędzie”?). Czy jednak tolerancja może być traktowana jako wartość „sama w sobie”, absolutna? Św. Paweł rozstrzyga ten problem w 1 Kor 8-10.

\subsection{Teza wynikająca z 1 Kor 8-10}

W 1 Kor 8-10 św. Paweł zaleca chrześcijanom posiadającym „wiedzę”, tzn. świadomym wymogów Ewangelii, postawę tolerancji wobec tych, którzy trwają w błędnym rozumieniu Ewangelii. Uzasadnia to dwoma zdaniami-kluczami. Niewłaściwą postawę tych, którzy posiadali „wiedzę” opisuje zdaniem: „«wie-

(por. 1 Kor 1,12: „każdy z was mówi: «Ja jestem Pawła, a ja Apollosa; ja jestem Kefasa, a ja Chrystusa»"), tłumaczy istnienie różnych opcji w tamtejszym Kościele. 
dza» wbija w pychę" (1 Kor 8,1). Zalecaną przez siebie korektę ich postawy zawiera w zdaniu: „Miłość buduje” (1 Kor 8,1). Miłość jest w tym zdaniu równoważnikiem zalecanej przez św. Pawła postawy tolerancji wobec tych, którzy nie przyjęli w pełni ewangelicznej „wiedzy”. Na tej podstawie można postawić tezę, że tolerancja jest funkcją miłości. Nie jest wartością „samą w sobie”, autonomiczną, ale jest podporządkowana miłości. Wydaje się, że zasadę tę należy traktować jako naczelną tezę, której podlega wszystko, co św. Paweł pisał na temat tolerancji (i nietolerancji) w innych tekstach.

\subsection{Problemy chrześcijan z Koryntu wynikające $z$ ich błędnego rozumienia Ewangelii}

Koryntianie nie zrozumieli właściwie Ewangelii głoszonej im przez św. Pawła, czego powodem było pomieszanie Ewangelii z ludzką mądrością i szukanie nadzwyczajnych doznań. Tendencję tę charakteryzują następujące pojęcia i zwroty: „mądrość"14, „poznanie"15, „żądni darów duchowych”16, „chlubić się"17, „pysznić się"18, „wszystko mi wolno”19. Koryntianie nie pojęli „teologii krzyża” głoszonej przez św. Pawła, ulegając tendencji, którą można nazwać „teologią chwały”. Ich postawę swoiście rozumianego elitaryzmu weryfikowało negatywnie samo życie.

W Kościele korynckim zaistniały podziały na różnych płaszczyznach, między innymi podział na „mocnych” i słabych” (por. 1 Kor 8-10). Św. Paweł miał informacje na ten temat dzięki listowi skierowanemu do niego przez chrześcijan $\mathrm{z}$ Koryntu ${ }^{20}$. Apostoł miał świadomość tego, że błędy popełniali zarówno „słabi”, jak i „mocni”:

a) Na czym polegał błąd „słabych”? Choć przyjęli oni Ewangelię głoszoną im przez św. Pawła, to ciągle mieszali ją z praktykami i wierzeniami z okresu sprzed nawrócenia. Chrześcijanie korynccy nie tworzyli za-

\footnotetext{
14 Słowo to występuje 17 razy w 1-2 Kor.

1516 razy w $1-2$ Kor.

161 Kor 14,12 .

171 Kor $1,29.31 .31 ; 3,21 ; 4,7 ; 13,3$.

181 Kor $4,6.18 .19 ; 5,2 ; 8,1 ; 13,4$.

191 Kor 6,12;10,23.

20 Zdanie zapisane w 1 Kor 8,1 rozpoczyna się od peri de (BT: „Jeżeli chodzi o...”) Taki sam początek zdania występuje w 1 Kor 1 Kor 7,1.25; 12,1; 16,1, sygnalizując w 1 Kor 7,1-15,58 odpowiedzi na kolejne problemy opisane w liście Koryntian skierowanym do
} św Pawła. 
mkniętego "getta” i włączali się w życie społeczności miasta; niektórzy uczestniczyli w ucztach, podczas których panował zwyczaj spożywania mięsa złożonego wcześniej w ofierze bożkom (zob. 1 Kor 8,1.4). Uczty te stanowiły nie tylko element obrzędowości religijnej, lecz także były swego rodzaju instytucją życia społecznego starożytności. Mięso dzielono na trzy części: jedną palono w świątyni na ołtarzu, drugą pozostawiano temu, kto składał lub finansował ofiarę, trzecią przeznaczano dla kapłanów obsługujących świątynię oraz do spożycia przez uczestników celebracji ${ }^{21}$. Chrześcijanie, których św. Paweł nazywa „słabymi w sumieniu” (1 Kor 8,10), spożywali te pokarmy „w przekonaniu, że chodzi o bożka” (1 Kor 8,7). Gorszyli się postępowaniem tych chrześcijan, którzy uważali, że mają do tego prawo (por. 1 Kor 8,9).

b) Pobłądzili także ci, których św. Paweł nazywa „mocnymi” (por. Rz 15,1). Uważali oni, że skoro realizują Ewangelię głoszoną przez Pawła, to mają "prawo [do takiego postępowania]" (1 Kor 8,9). Upoważniała ich do tego „wiedza” o tym, „że nie ma na świecie ani żadnych bożków, ani żadnego boga, prócz Boga jedynego" (1 Kor 8,4). Na czym polegał ich błąd? Już z pierwszego zdania sekcji listu zawartej w 1 Kor 8-10 poznajemy ocenę ich postępowania dokonaną przez św. Pawła. „Wiedza” wbijała ich w pychę. Brakowało im miłości, która buduje.

\subsection{Korekta postawy Koryntian dokonana przez św. Pawła}

Św. Paweł zwraca się do tych chrześcijan z Koryntu, którzy stali na gruncie obiektywnej prawdy. Poleca im, aby zmienili swą postawę w stosunku do „słabych w sumieniu". Kluczowe jest zdanie zawarte w 1 Kor 8,1:

"Jeżeli chodzi o pokarmy składane bożkom w ofierze,

to oczywiście wszyscy posiadamy «wiedzę».

Lecz «wiedza» wbija w pychę,

miłość zaś buduje”.

Św. Paweł dał do zrozumienia „mocnym”, że nie wystarczy to, że po ich stronie leży obiektywna racja („wiedza”, którą podzielał też św. Paweł), ale w jej

21 Zob. G.G. Fee, The First Epistle to the Corinthians, Grand Rapids1973, s. 359-361. Inaczej widzi istotę problemu ks. K. Romaniuk, Pierwszy List do Koryntian, w: Komentarz praktyczny do Nowego Testamentu, A. Jankowski, K. Romaniuk, L. Stachowiak (red.), t. 2, Poznań - Warszawa 1975, s. 733: Jeśli ofiara była wielka, i nie zdołano spożyć mięsa, to sprzedawano je potem w sklepach. W takich okolicznościach miał powstać problem, czy chrześcijanom godzi się kupować mięso, którego część złożono w ofierze bożkom. 
egzekwowaniu powinni oni wziąć poprawkę na opinię „słabych”. Taki jest wymóg miłości, która buduje.

Św. Paweł ocenia postępowanie „oświeconych «wiedzą»” jako grzech godzący nie tylko w braci „słabych w sumieniu”, ale także jako grzech przeciwko Chrystusowi (1 Kor 8,11-12). Ci, którzy miłują Boga i są uznani przez Boga (1 Kor 8,3) i uznają, że jest jeden Bóg, Ojciec, i jeden Pan, Jezus Chrystus (1 Kor 8,6), powinni korzystać ze swej „wiedzy” w sposób, który buduje wiarę braci, choćby to powodowało rezygnację z własnych praw (1 Kor 8,1-3.13). Tym, co buduje innych, jest miłość, a nie aroganckie korzystanie $\mathrm{z}$ „wiedzy” wbijające w pychę $(1$ Kor 8,1). W 1 Kor 9 św. Paweł podaje siebie za przykład w realizowaniu zasady samoograniczenia motywowanego miłością. Kluczowe jest stwierdzenie zawarte w 1 Kor 9,18: „nie korzystam z praw, jakie mi daje Ewangelia”. Sam Paweł zdecydował się na samoograniczenie, powodowany miłością do tych, którym głosi Ewangelię. A przecież miał pełen tytuł do przywilejów należnych głosicielom Ewangelii, a wśród nich - do wsparcia materialnego przez wiernych. Jest przecież autentycznym apostołem (1 Kor 9,1-2): widział Jezusa, Pana naszego (pod Damaszkiem), został przez Niego posłany do pogan, a wśród nich do Koryntian, a dowodem skuteczności jego pracy jest przyjęcie wiary przez samych Koryntian. Paweł wskazuje na siebie jako na tego, który rozumie Ewangelię lepiej od Koryntian, gdyż spotkał samego Jezusa. Obok członków Kościoła w Koryncie, którzy akceptowali prawo Apostoła do przyjmowania $\mathrm{z}$ ich strony wsparcia finansowego (1 Kor 9,1-2), byli tacy, którzy to prawo kwestionowali (1 Kor 9,3-14), mimo że Apostoł doznawał niedostatku (por. 1 Kor 4,11-13). W tej sytuacji Apostoł zrezygnował ze swojego prawa, które dawała mu Ewangelia (1 Kor 9,18), uznając, że taka postawa przysłuży się głoszeniu Ewangelii, a odpłatę otrzyma od samego Boga (1 Kor 9,15-18.23). Paweł stał się niewolnikiem wszystkich, aby tym liczniejsi byli ci, których pozyska (1 Kor 9,19), choć, przynależąc do Chrystusa, był przecież wolny (1 Kor 9,20-22). Trwanie w postawie samoograniczenia, której celem był udział w Ewangelii, porównuje do treningu sportowców, którzy poświęcają wiele trudu po to, aby otrzymać nagrodę (1 Kor 9,24-27). W 1 Kor 10,1-10 św. Paweł podaje przykład z historii Izraela, aby wykazać, czym skończy się zaniedbanie miłości ze strony Koryntian „oświeconych «wiedzą»". Izraelici, których Bóg prowadził przez pustynię pod wodzą Mojżesza, otrzymali od Boga, mocą przyszłych zasług Chrystusa, duchowy pokarm i duchowy napój, a mimo to niektórzy z nich ulegli bałwochwalstwu, rozpuście i szemraniu, za co spotkała ich kara (1 Kor 10,1-10). „Niech przeto ten, komu się zdaje, że stoi, baczy, aby nie upadł” (1 Kor 10,12). Kolejnym argumentem na rzecz samoograniczenia jest analogia między ucztą, podczas której uczestnicy wchodzą w zażyłość między sobą, i gromadzeniem się chrześcijan na piciu kielicha i łamaniu chleba, podczas którego 
wchodzą w zażyłość z Chrystusem. Analogicznie, uczestnicząc w spożywaniu mięsa składanego w ofierze demonom, wchodzi się w krąg działania demonów (1 Kor 10,14-22). Kolejnym argumentem za postawą samoograniczenia jest korekta zasady, którą Paweł głosił w Koryncie i na którą powoływali się jego przeciwnicy: „Wszystko mi wolno”. Apostoł dodaje: „Wszystko mi wolno, ale nie wszystko przynosi korzyść”; „....ale nie wszystko buduje”. Stąd wyprowadza zasadę nadrzędności dobra bliźniego nad dobrem własnym. Trzeba zwracać uwagę na "maluczkich”, a nie tylko kierować się własnymi racjami (10,23-24). Przeto: „Jeżeli zaprosi was ktoś z niewierzących, a wy zgodzicie się przyjść, jedzcie wszystko, co wam podadzą, nie pytając o nic - dla spokoju sumienia. A gdyby ktoś powiedział: «To było złożone na ofiarę» - nie jedzcie przez wzgląd na tego, który was ostrzegł i z uwagi na sumienie. Mam na myśli sumienie nie twoje, lecz bliźniego” (1 Kor 10,27-29a). „Niech nikt nie szuka własnego dobra, lecz dobra bliźniego!” (1 Kor 10,24). W końcowej części wywodu Apostoł raz jeszcze podaje siebie za przykład właściwej postawy (1 Kor 10,31-32).

Kierunek zmian, w jakim powinni zmierzać „mocni” wobec „słabych” dobrze oddają zwroty użyte przez nas w definicji tolerancji podanej we wstępie artykułu jako „zrzeczenie się” egzekwowania prawdy, „znoszenie drugich w ich inności”. Św. Paweł łączy nakaz tolerancji z zaleceniem przyjęcia postawy samoograniczenia $\mathrm{w}$ korzystaniu $\mathrm{z}$ należnych praw, oceniając postawę przeciwną jako wynik pychy. Pochodną miłości jest tolerancja.

\subsection{Wnioski praktyczne z 1 Kor 8-10 związane z problemem tolerancji}

Choć geneza konfliktu w Kościele korynckim czasów św. Pawła była związana z realiami historycznymi, które nie są już dziś aktualne, to jednak spór między chrześcijanami „mocnymi” i „słabymi” ma swoje analogie w Kościele naszych czasów. Ci, którzy stoją na gruncie ortodoksji, stają wobec pytania, jak zachować się wobec współbraci, którzy nie stosują zasad Ewangelii. „My” należymy do tych, którzy, mówiąc słowami św. Pawła, posiadają „wiedzę”, a „oni” są „słabi” w wierze. Najprostszy schemat postępowania, który narzuca się w takich okolicznościach u tych, którzy są "oświeceni «wiedzą»" (zastosowali go chrześcijanie korynccy i jest on niejednokrotnie stosowany po dzień dzisiejszy), polega na trwaniu na pozycjach „wiedzy” i czekaniu na to, że „słabi” zmienią swe postępowanie. Ten schemat postępowania wydaje się być jedynie słuszny, a jednak św. Paweł każe na niego popatrzeć krytycznie.

Trzeba zwracać uwagę na opinię bliźnich, a nie tylko kierować się obiektywną racją, „wiedzą”. Pamięć o tym, jak nasze postępowanie mogą odebrać inni, powinna skłaniać do czujności. Konieczne jest cierpliwe akceptowanie "słabych", a więc postawa tolerancji. Łączy się ona z samoograniczeniem w re- 
alizacji ,jedynie słusznej prawdy” czy swoich praw. Taka postawa ma sens tylko wtedy, gdy ktoś kieruje się miłością bliźniego, skoro pojęciem nadrzędnym wobec tolerancji jest miłość. Tolerancja nie jest więc pojęciem „akademickim” w tym sensie, że praktyczne rozumienie Ewangelii, które „buduje” (zob. 1 Kor $8,1 b$ ) dokonuje się dopiero $\mathrm{w}$ dialogu $\mathrm{z}$ innymi i jest owocem miłości.

Dotyczy to wspólnoty Kościoła. Spoiwem wspólnoty Kościoła jest miłość zakładająca tolerancję, a nie tylko "administracyjne” egzekwowanie prawdy. Tylko atmosfera miłości, wybaczenia błędów, jest w stanie przeciągnąć na stronę prawdy Ewangelii tych, którzy są poza Kościołem lub są jego słabą cząstką. Analiza 1 Kor 8-10 w pełni potwierdza tezę zacytowaną we wstępie artykułu: „Noszenie brzemienia drugiego, albo przyjęcie brata jako zbawczy krzyż jest jednym z podstawowych wymogów Ewangelii (Ga 6,2). Tam, gdzie między chrześcijanami nie ma tolerancji, niewłaściwie jest rozumiane prawo Chrystusa. Uderzająca jest tolerancja Pawła Apostoła wobec jego wrogów: «a jeśli odczuwacie coś inaczej, i to Bóg wam objawi» (Flp 3,15)” (A. Grabner-Heider). Miłość nie pozwala na zamykanie się w kręgu swoich poglądów, „wiedzy” i każe zwracać uwagę na poglądy tych, którzy mają inne od nas zdanie (przeciwna postawa byłaby, w ocenie św. Pawła, przejawem pychy). Miłość domaga się wychodzenia ku innym, ze świadomością ich słabości. Ma tendencję do przekraczania granic, do wychodzenia ku ludziom „obcym” pod względem kulturowym, ideowym, religijnym.

Samoograniczenie, które zaleca św. Paweł Koryntianom, jest jednym z ideałów duchowości chrześcijańskiej. Asceza, dyscyplina wewnętrzna (można ją nazwać nietolerancją wobec siebie samego), jest obecna w życiu wielu wybitnych postaci w historii Kościoła ${ }^{22}$.

Postawa taka nie ma nic wspólnego ze stereotypem, który funkcjonuje w dzisiejszym świecie, według którego powiedzenie o jakiejś osobie czy instytucji, że jest tolerancyjna, oznacza jej pochwalenie, zaś powiedzenie, że jest nietolerancyjna, jest równoznaczne z jej napiętnowaniem, gdyż w stereotypie tym tolerancja jest traktowana jako wartość absolutna, autonomiczna. Nieuprawnione jest używanie pojęcia tolerancji do opisu czynów, które nie są motywowane miłością (wynikać one mogą np. z koniunkturalizmu).

22 M. van der Meersch, Mała święta Teresa, Warszawa 1972, s. 171: „O, kiedy pomyślę, ile jeszcze muszę zdobyć!” - woła jedna z nowicjuszek. „Powiedz raczej: stracić” - odpowiada Teresa. Tak, stracić! Trzeba stracić uparte dążenie do powodzenia, szał zbierania zasług. Trzeba stracić pewność siebie, gromadzenie zasług i ten wieczny, dręczący rachunek: „winien” i „ma”. Trzeba wreszcie stracić pychę! „Chcesz zdobyć szczyt górski. A dobry Bóg chce cię sprowadzić w dół, czeka na ciebie w żyznej dolinie pokory”. „Pokora - to prawda!”. 
Postawa zalecana przez św. Pawła dotyczy relacji w rodzinie. Trudno wyobrazić sobie życie w rodzinie bez „przymykania oczu” na wzajemne słabości w imię miłości. Dotyczy to także relacji: szef - podwładny.

Zasada wynikająca z 1 Kor 8,1 nie zamyka refleksji nad zjawiskiem tolerancji, a jedynie pokazuje tło zasadniczego problemu, którym jest współistnienie tolerancji i nietolerancji w życiu chrześcijanina. W 1 Kor 8-10 nie znajdujemy odpowiedzi na pytanie, czy zalecenie tolerancji jest obligatoryjne w każdych okolicznościach, czy tylko w niektórych, a jeśli w niektórych, to w jakich. Do problemu stosowania zasady tolerancji przejdziemy w artykule, który zostanie opublikowany w kolejnych numerze „Biblica et Patristica Thoruniensia”

\section{Bibliografia}

Egger W., Metodologia del Nuovo Testamento. Introduzione allo studio scientifico del Nuovo Testamento, Bologna 1989.

Fee G.G., The First Epistle to the Corinthians, Grand Rapids1973.

Grabner-Haider A., Tolerancja, w: Praktyczny Słownik Biblijny, Opracowanie zbiorowe katolickich i protestanckich teologów, A. Grabner-Haider (red.), T. Mieszkowski, P. Pachciarek (przekład i opracowanie), Warszawa 1995 (oryginał: Freiburg im Breisgau 1969).

Jougan A., Słownik kościelny łacińsko-polski, Warszawa 1992.

Pesce M., Le due fasi della predicazione di Paolo. Dall'evangelizzazione alla guida della comunità, Bologna 1994.

Romaniuk K., Pierwszy List do Koryntian, w: Komentarz praktyczny do Nowego Testamentu, A. Jankowski, K. Romaniuk, L. Stachowiak (red.), t. 2, Poznań - Warszawa 1975.

Meersch van der M., Mała święta Teresa, Warszawa 1972. 